Pobrane z czasopisma Annales N - Educatio Nova http://educatio.annales.umes.pl Data: 26/04/2023 13:36:03

DOI: 10.17951/en.2018.3.125-142

\begin{tabular}{lcr}
\hline & ANNALES \\
& UNIVERSITATIS MARIAE CURIE-SKLODOWSKA & \\
LOL. III & SECTIO N & 2018 \\
\hline
\end{tabular}

Jolanta Fiszbak

Uniwersytet Łódzki

ORCID: https://orcid.org/0000-0002-7852-650X

jolanta.fiszbak@uni.lodz.pl

\title{
Zmierzch zawodu nauczyciela czy niedookreśloność potrzeb społeczeństwa ponowoczesnego?
}

\section{The Fall of Teaching or Imprecise Needs of the Post-Modern Society?}

\begin{abstract}
Streszczenie: Autorka omawia sylwetki czterech polonistek i poddaje krytyce głoszone obecnie twierdzenia o potrzebach zmian w pracy nauczyciela i nauczaniu. Na tej podstawie dowodzi, że wiek XXI nie jest początkiem końca szkoły i zawodu nauczyciela, mimo istnienia alternatywnych form kształcenia. W konkluzji stwierdza, że młodzież nadal potrzebuje mądrego, życzliwego, świadomego swojej roli i dobrze wykształconego przewodnika. Ponowoczesność zaś przestała już niepokoić, choć nadal zaskakuje zmianami. Można więc spokojniej podejść do problemów kształcenia szkolnego, wykorzystać w nim wypracowane osiągnięcia polskiej dydaktyki i bez pośpiechu zastanowić się nad wzorami obcymi.
\end{abstract}

Słowa kluczowe: nauczyciel; nauczanie; potrzeby ponowoczesnej szkoły 


\section{WPROWADZENIE}

Zawodowi nauczyciela poświęcono wiele miejsca w polskiej literaturze dydaktycznej. Przywołać należy choćby znane i klasyczne już prace Jana W. Dawida, Stefana Baleya, Zygmunta Mysłakowskiego, Stefana Szumana ${ }^{1}$. Rzeczywistość „płynnej ponowoczesności” zdaje się jednak sugerować, że wskazywane przez nich pożądane właściwości postawy nauczycielskiej trzeba odłożyć do lamusa i szukać innych zestawów cech ważnych dla pedagoga doby ponowoczesnej. Powodów tego stanu rzeczy należy szukać w zaburzeniu kształtowanego przez stulecia nowoczesnego ładu ekonomicznego, społecznego i kulturowego, którego wyraziste i stabilne dotąd wzorce i granice uległy rozmyciu². Dla współczesności charakterystyczne są takie tendencje, jak: gwałtowny rozwój neoliberalnego kapitalizmu rynkowego i demokracji; wpływ nowych technologii na wszystkie sfery życia; łatwy przekaz informacji oraz szybki sposób ich przetwarzania; rozpad tradycyjnych struktur społecznych, będący skutkiem ukształtowania się społeczeństwa sieci; dominacja popkultury; zmiany w zakresie pojmowania tożsamości narodowej ${ }^{3}$.

Gwałtowne i ciągłe zmiany współczesności powodują bezradność dorosłych, wpływają również na dorastające pokolenie. Tomasz Goban-Klas zwraca uwagę, że wielu naukowców, dziennikarzy i pedagogów prezentuje sceptyczny, negatywny, a nawet cyniczny pogląd na „pokolenie sieci” (w 2003 roku w USA pojawiło się określenie dumbiest generation - „najgłupsze pokolenie”). Twierdzą oni między innymi, że współcześni młodzi ludzie są głupsi niż poprzednie pokolenia w ich wieku, są uzależnionymi od sieci ekranowcami pozbawionymi umiejętności społecznych, nie mają poczucia wstydu, stracili orientację w świecie i obawiają się wyboru własnej drogi życiowej, naruszają prawa własności intelektualnej, nękają innych użytkowników internetu, są nadpobudliwi, nie mają etyki pracy,

1 J.W. Dawid, O duszy nauczycielstwa, Warszawa 1912; S. Baley, Psychologia wychowawcza w zarysie, Warszawa 1958; Z. Mysłakowski, Pisma wybrane, Warszawa 1971; S. Szuman, Takt pedagogiczny, Katowice 1974. Zob. także późniejsze prace, np.: J. Kowalikowa, Składniki polonistycznej kompetencji nauczycielskiej, „Zeszyty Naukowe UJ. Prace Historycznoliterackie” 1982, z. 44, s. 11-17; R. Schulz, Nauczyciel jako innowator, Warszawa 1989; Kompetencje wspótczesnego polonisty, red. B. Chrząstowska, Warszawa 1997; J. Kuźma, Nauczyciele przyszłej szkoty, Kraków 2001; R. Kwaśnica, Wprowadzenie do myślenia o nauczycielu, [w:] Pedagogika. Podręcznik akademicki, red. Z. Kwieciński, B. Śliwerski, t. 2, Warszawa 2003; C. Plewka, Uwarunkowania zawodowego rozwoju nauczycieli, Warszawa 2009; W kręgu danych $i$ wspótczesnych teorii wychowania. Uczeń - szkoła - nauczyciel, red. K. Dormus, R. Ślęczka, Kraków 2012.

2 S. Gajda, Wychowanie językowe wobec ponowoczesności, [w:] Wychowanie językowe, red. J. Nocoń, Opole 2015, s. 17.

3 Ibidem, s. 17-18. 
niczym się nie przejmująa ${ }^{4}$ Inną charakterystykę tego pokolenia przedstawił Don Tapscott. Zwrócił uwagę, że korzystający z internetu młodzi ludzie wyznaczają trendy w rozwoju nowoczesnych technologii, chcą zmian w metodach nauczania, próbują narzucić swoje wartości. Nie cenią tych, którzy nie chcą myśleć, jak oni. Nie interesuje ich prywatność. Gdy uczniowie chcą się czegoś dowiedzieć, informacji szukają w internecie lub pytają rówieśników na forach; rzadko zwracają się do nauczyciela. Tapscott zauważa jednak, że pokolenie sieci posiada potencjał, którego nie wolno lekceważyć. Charakterystycznymi jego cechami są: wolność, dopasowywanie do własnych potrzeb (zjawisko kastomizacji ${ }^{5}$ ), baczna obserwacja, wiarygodność, współpraca, rozrywka, szybkie tempo, innowacyjność; znaczącą cechą umysłowości tego pokolenia jest szybkość przetwarzania informacji wizualnych i zdolność szybkiego dostrzegania ${ }^{6}$. Badacz podkreślił, że dla tego typu umysłowości współczesna szkoła ze sprawdzonymi procedurami jest - w porównaniu z rzeczywistością wirtualną - pospolita, a metody przestarzałe i nieatrakcyjne ${ }^{7}$.

Wiele zdaje się wskazywać na to, że w dobie „płynnej ponowoczesności” nauczyciele tracą wpływ na rzeczywistość, w jakiej żyją uczniowie, a dotychczasowa ich rola w procesie edukacji zdezaktualizowała się i powinna być zastąpiona inną. $\mathrm{Z}$ tego powodu obserwuje się zwrot $\mathrm{w}$ stronę e-learningu, $\mathrm{w}$ którym zadania nauczyciela są odmienne od tradycyjnych. Jedną z propozycji jest wprowadzenie na grunt dydaktyki szkolnej opiekuna naukowego $\left(\right.$ tutora $\left.^{8}\right)$ oraz osobistego trenera $\left(\right.$ coacha $\left.^{9}\right)$, których działanie opiera się na innych zasadach niż praca nauczyciela. Akcentowanie potrzeby zmian w edukacji oraz pracy nauczyciela jest wymuszane jeszcze innymi, niż wskazane wcześniej, tendencjami, jak: zanik autorytetów; zmiana stosunku do wiedzy, która przestała być wartością samą w sobie, i rozumu; przejście od eksponowania zakorzenienia narodowego i religijnego, w którym ważną rolę odgrywał nauczyciel, do wartości uniwersalnych,

4 T. Goban-Klas, Nowa edukacja medialna w społeczeństwie ryzyka i katastrof, „Edukacja i Dialog" 2010, nr 9.

5 Zob. W. Kołodziejczyk, M. Polak, Jak będzie zmieniać się edukacja. Wyzwania dla polskiej szkoty i ucznia, Warszawa 2011.

6 D. Tapscott, Cyfrowa dorostość. Jak pokolenie sieci zmienia świat, Warszawa 2010, s. 140, 182.

7 Ibidem, s. 255.

8 Zob. np. Tutoring - poznaj innowacyjna metodę, http://tutoring.edu.pl/tutoring_definicja_innowacyjna_metoda,page,46 [dostęp: 22.09.2017].

9 Profesjonalny coach, czyli kto?, www.competitiveskills.pl/aktualnosci/profesjonalny-coach-czyli-kto-226.html [dostęp: 22.09.2017]; A. Zadroga, Coach, czyli kto?, http://wyborcza. pl/1,76842,8563661,Coach_czyli_kto_.html [dostęp: 22.09.2017]; K. Urbaniak, Kim jest coach i co może dla Ciebie zrobić - wywiad z Adamem Gieniuszem, http://kreatorniazmian.pl/kimjest-coach-co-to-jest-coaching/\#sthash.uQrsU6oi.dpuf [dostęp: 22.09.2017]. 
kosmopolitycznych. Stwierdza się również, że nie do końca wiadomo, kto obecnie pełni rolę nauczyciela, a kto ucznia, a nauczyciel przestał być dziś jedynym medium wiedzy ${ }^{10}$. Sygnalizuje się ponadto potrzebę wypracowania nowych strategii nauczania-uczenia się, ponieważ uznano, że dotychczasowy typ nauczania jest anachroniczny i nie nadąża za potrzebami gospodarki wolnorynkowej: sprawdzał się w gospodarkach kapitalistycznych, w których wiedza stanowiła potęgę i dawała podstawę do poprawy bytu. W gospodarkach ponowoczesnych, w których rządzi rynek, decydują o tym umiejętności wypracowane przez odpowiednio ukierunkowane na pracodawców szkoły ${ }^{11}$.

Celem niniejszych rozważań jest próba odpowiedzi na pytania, czy rzeczywiście „płynna ponowoczesność” wymaga radykalnych zmian w systemie kształcenia, czy zdezaktualizował się istniejący dotąd, pożądany przez uczniów i społeczeństwo, model (wzór) pedagoga oraz w jakim stopniu ulegamy sądom o potrzebie zmian, wynikającym z potrzeb społeczeństwa ponowoczesnego, a które nazwać możemy mitami - tyleż nośnymi znaczeniowo, co nie do końca prawdziwymi. W tym celu najpierw przedstawimy sytuację zawodową nauczycieli w krajach Zachodu, które już dawno przeszły transformację społeczno-kulturową i w pełni są krajami ponowoczesnymi, oraz w krajach wchodzących w tę fazę rozwoju lub dopiero pretendujących do niej. Następnie zostaną zaprezentowane sylwetki zawodowe czterech polonistek, które odniosły sukces w swojej pracy, są lubiane i cenione przez uczniów oraz ich rodziców. Na końcu uwaga zostanie zwrócona na wspomniane sądy/twierdzenia o potrzebie zmian w pracy nauczycieli i nauczaniu, które przyjmuje się bezdyskusyjnie, tymczasem można i należy z nimi polemizować.

\section{POSTRZEGANIE ZAWODU NAUCZYCIELA W POLSCE I POZA JEJ GRANICAMI}

Na łamach czasopisma „Edukacja i Dialog”, którego jeden z numerów w całości poświęcono zawodowi nauczyciela ${ }^{12}$, znajdują się interesujące uwagi na temat roli, pracy, statusu oraz rangi osób wykonujących w różnych państwach tę profesję. W Turcji od najmłodszych lat rodzice wpajają dzieciom, że nauczyciel jest osobą bardzo ważną, którą mają szanować. Co więcej, rola nauczyciela się zmienia. Jest postrzegany już nie tylko jako pedagog, wychowawca, lecz często

10 Zob. np. S. Gajda, op. cit., s. 17-25.

11 Ibidem.

12 „Edukacja i Dialog” 2015, nr 1-2. 
także jako „przyjaciel”, co czasem rodzi problemy ${ }^{13}$. „W Armenii praca nauczycieli jest jedną z najwyższych profesji w kraju. Są oni powszechnie szanowani i mają wielki autorytet nie tylko wśród uczniów, ale i wśród wszystkich obywateli. Zawód ten jest bardzo ceniony, a poziom kształcenia w państwie jest nadzwyczaj wysoki" ${ }^{14}$. W krajach ponowoczesnych sytuacja zdaje się być zgoła odmienna. W Wielkiej Brytanii „zapomniano dawać nauczycielom szacunek, na jaki zasługują". Od kilku lat jednak, jak stwierdza Estera Chhabra, rząd pracuje nad zmianą tej sytuacji ${ }^{15}$. W Niemczech "Zauważa się wzrastającą liczbę nauczycieli, którzy nie identyfikują się ze szkołą bądź nie przykładają się do pracy, oraz malejącą liczbę tych nauczycieli, którzy są naprawdę dobrymi pedagogami, jednak ich praca i zaangażowanie w wykonywany zawód nie zostały przez nikogo docenione i odpowiednio wynagrodzone" ${ }^{\text {. }}$. Francuskich nauczycieli spotyka „Brak pozytywnych reakcji uczniów i rodziców, kwestionowanie autorytetu, przemoc fizyczna i werbalna [...], coraz bardziej wydłużający się czas pracy, nieatrakcyjne zarobki [...]"17. Bywają też odstępstwa od tej reguły - nie zawsze w krajach, którym daleko do ponowoczesności, zawód nauczyciela jest doceniany: „Zawód nauczyciela nie cieszy się w Egipcie żadnym szacunkiem. Szkolni wykładowcy kojarzeni są przede wszystkim z niedbałością, brakiem zaangażowania, obarczani są odpowiedzialnością za niewłaściwe przekazywanie wiedzy. Uczniowie najczęściej nie znajdują w nauczycielach autorytetów i nie chcą podążać za ich przykładem". Marta Abd Elsamie zauważa przy tym, że do pracy w szkołach publicznych zniechęcają nauczycieli niskie płace i złe warunki pracy ${ }^{18}$.

Na takie niedogodności zawodu, jak: brak odpowiedniego wynagrodzenia, złe warunki pracy, brak uznania i szacunku, coraz bardziej wydłużający się czas pracy, coraz większe wymagania władz oświatowych, stres wywołujący wypalenie zawodowe - wskazują nauczyciele państw ponowoczesnych, w tym nauczyciele polscy, przy czym ich wynagrodzenie jest realnie dużo niższe niż kolegów w Unii. Minęły czasy, gdy przynajmniej niektórzy uczeni, np. renesansowi humaniści Andrzej Frycz Modrzewski i Szymon Maricjusz (lub Marycjusz) z Pilzna, cenili zawód nauczyciela. Modrzewski pracę pedagogów utożsamiał

13 A. Tkaczyk, Nauczyciel a edukacja w Turcji, „Edukacja i Dialog” 2015, nr 1-2, s. 63.

14 R. Khachatryan, Ormiański nauczyciel - jeden z głównych filarów narodu, „Edukacja i Dialog" 2015, nr 1-2, s. 66.

15 E. Chhabra, Teacher - popyt na nauczyciela w Wielkiej Brytanii, „Edukacja i Dialog” 2015, nr 1-2, s. 60.

16 K. Tomasik-Abdelsamie, Nauczyciel w Niemczech, „Edukacja i Dialog” 2015, nr 1-2, s. 55.

17 M. Troc-Rezaiguia, Kim jest dzisiejszy francuski nauczyciel, „Edukacja i Dialog” 2015, nr 1-2, s. 57.

18 M. Abd Elsamie, Profesja nauczyciela w Arabskiej Republice Egiptu, „Edukacja i Dialog” 2015, nr 1-2, s. 62. 
z misją starożytnych mędrców - filozofów, obaj zaś uważali, że w zasługach dla państwa „stan nauczycielski” równy jest królom i biskupom ${ }^{19}$. Znaczenie tego zawodu dostrzegali również oświeceniowi myśliciele i uczeni działający w Komisji Edukacji Narodowej. Jednym z celów jej działania było podniesienie rangi i autorytetu zawodu nauczycielskiego w społeczeństwie. Ustawy Komisji z 1783 roku powołały odrębny „stan akademicki”, do którego należeli profesorowie uniwersytetów i nauczyciele szkół średnich ${ }^{20}$. Rzadko kiedy jednak w dziejach naprawdę szanowano zawód nauczyciela, mimo że dostrzegano jego znaczenie dla państwa i obywateli. Wspomniany Maricjusz ubolewał nad poniżeniem „stanu nauczycielskiego" i zastanawiał się, dlaczego „ten święty, zacny i dla Rzeczypospolitej niezbędny urząd tak niegodnie się traktuje i prawie zniewala"21. Nie inaczej jest dzisiaj, choć stale podkreśla się powinności nauczyciela, a on sam zobowiązany jest posiadać wysokie wykształcenie. Zawód ten na Zachodzie nie jest nawet zaliczany do zawodów klasy średniej.

\section{POŻADANE SPOŁECZNIE CECHY ZAWODOWE NAUCZYCIELI}

Mimo spadku znaczenia zawodu nauczyciela znajdujemy w Polsce niemałą grupę pedagogów, którzy uważają siebie za spełnionych zawodowo i jakkolwiek mówią o coraz trudniejszych warunkach pracy, nadal uczą z pasją. Niżej zostaną przedstawione sylwetki czterech nauczycielek języka polskiego, które cieszą się autorytetem oraz uznaniem uczniów i ich rodziców. Osiągają też wysokie wyniki nauczania, co znajduje odzwierciedlenie w wynikach testów kompetencji szkolnych. Należy podkreślić, że żadna nie uczy „pod testy”, choć do nich przygotowują. Innym miernikiem ich osiągnięć jest wysoki poziom językowy, umiejętności oraz wiedza przedmiotowa ich uczniów. Wszystkie polonistki charakteryzują się pożądaną elastycznością względem proponowanych zmian edukacyjnych $^{22}$. Dwie z nich - Ewa Popiel-Popiołek i Małgorzata Trajdos-Kursa - są nauczycielkami gimnazjum, Elżbieta Pełzowska uczy w szkole podstawowej,

19 P. Mazur, Zawód nauczyciela w ciagu dziejów. Skrypt dla studentów z historii wychowania, Chełm 2015, s. 45-46.

20 Ibidem, s. 61.

21 Ibidem, s. 46.

22 Zaprezentowane w rozważaniach uwagi są oparte na wieloletniej obserwacji pracy prezentowanych polonistek, trwającej w przypadku dwóch z nich nawet 20 lat. Czas ten pozwolił nie tylko określić ich cechy zawodowe, ale również wydobyć łączące je z uczniami relacje oraz stosunek zmieniających się roczników do coraz starszych nauczycielek. Dodatkowych informacji na temat ich pracy dostarczyły przeprowadzone w listopadzie 2017 roku badania, które objęły m.in. uczniów trzech spośród prezentowanych w rozważaniach nauczycielek (wyniki badań zostały skierowane do druku w tomie pokonferencyjnym Dydaktyka polonistyczna wobec przemian XXI wieku). 
a Barbara Strzelecka - w liceum. Wszystkie w pewnym okresie swojego życia zawodowego były nauczycielkami drugiego etapu edukacyjnego, ponadto współpracowały lub współpracują z Zakładem Dydaktyki Języka i Literatury Polskiej UŁ jako nauczycielki szkół ćwiczeń; dwie pracowały w tym Zakładzie, kształcąc nauczycieli polonistów; trzy są autorkami publikacji o charakterze dydaktycznym i naukowo-dydaktycznym. Należy także zwrócić uwagę na wiek tych polonistek - dorastały w okresie PRL-u i wychowały się w czasach silnego oddziaływania ideologii socjalistycznej. Najstarsza znacznie przekroczyła wiek emerytalny (ma 69 lat) i nadal chciałaby pracować, choć na pewno nie w pełnym wymiarze godzin; dwie wiek ten osiągnęły (mają po 60 lat) i do przejścia na emeryturę zmusiły je niekorzystne relacje między „starą" a „nową" emeryturą; jedna należy do pokolenia średniego (znacznie przekroczyła 50. rok życia). Nie są to osoby bardzo młode, a jednak - mimo że młodzież szkolna woli młodszych nauczycieli, bliższych jej wiekiem i doświadczeniem pokoleniowym - są nie tylko akceptowane, ale też pożądane jako nauczycielki. Najstarsza spotyka się z prośbami uczniów, by zechciała uczyć ich klasę, najmłodsza lubiana jest nawet przez uczniów, którzy nie są miłośnikami języka polskiego (przedmiotów humanistycznych) - jej uczniowie zaznaczają w rozmowach, że nauczanie przez nią języka polskiego „to już inna historia” lub że „Pani jest w ogóle poza wszelką konkurencją". Jedna z uczennic, uzasadniając, dlaczego lubi język polski, napisała w ankiecie: „Bo Pani Pełzowska jest najlepsza”.

Mimo różnic charakterologicznych, co oczywiste, oraz wynikających z wieku i doświadczeń życiowych wszystkie posiadają cechy wspólne. Przede wszystkim warto zwrócić uwagę na to, co stanowi podstawę zawodu nauczyciela - na doskonałe przygotowanie merytoryczne i metodyczne. Wszystkie polonistki posiadają bogatą wiedzę przedmiotową z zakresu literaturoznawstwa i językoznawstwa oraz dyscyplin, które współtworzą przedmiot zwany językiem polskim, np. z filozofii, historii, różnych dziedzin sztuki, a także z szeroko pojętej kultury. Do tego dochodzi nieustające zainteresowanie światem i chęć jego poznawania jako stała predyspozycja osobowości. To m.in. ona powoduje ciągłą pracę nad warsztatem metodycznym, wyzwala potrzebę poznania nowości i ich weryfikację w praktyce. Dzięki niej także wszystkie Panie potrafią obsługiwać komputer i wykorzystywać możliwości, jakie daje to medium. Najmłodsza z nich pozwala również podczas lekcji korzystać z internetu za pomocą smartfonu, by uczniowie mogli sprawdzić to, o czym zapomnieli, lub odszukać jakąś informację. Inna, by oszczędzić czas lekcyjny, którego w liceum ciągle brakuje, wprowadziła prace klasowe i sprawdziany online. Prowadzi też stroną internetową, na której komunikuje się z uczniami. Nauczycielki gimnazjum wykorzystują w tym celu możliwości, jakie daje program Librus. Nie wszystkie jednak są tak biegłe, jak ich 
uczniowie w obsłudze nowoczesnych urządzeń, do czego przyznają się i nie widzą problemu, by prosić młodzież o pomoc. Ta ciągła chęć poznawania owocuje potrzebą przyjrzenia się zainteresowaniom uczniów. Wszystkie dobrze się w nich orientują i choć nie zawsze je akceptują, nie poddają ich ujemnemu wartościowaniu - charakteryzuje je umiejętność bezkonfliktowego wyrażania ocen, jeśli uznają, że powinny zaznaczyć, dlaczego np. taka lub inna forma rozrywki im nie odpowiada. Potrafią bliżej zainteresować się fascynacjami uczniów i poświęcić im swój czas. Jeśli coś je zaciekawi, proszą o wprowadzenie i wyjaśnienia. Prośby te wypływają z autentycznej potrzeby poznawczej.

Ważnym zespołem cech prezentowanych nauczycielek jest pasja, z którą wykonują swój zawód, zapał do pracy i poważne traktowanie obowiązków. W ich pracy uczeń jest najważniejszy i wszystko podporządkowane jest rozwojowi jego osobowości. Przejawia się to w różny sposób, np. w systematycznym sprawdzaniu różnego rodzaju prac pisemnych (w tym stylistycznych), a w szkole podstawowej także zeszytów uczniowskich, oraz w stosowaniu takich zadań, by uczniowie byli zainteresowani starannym prowadzeniem zeszytów. Innym rodzajem zachęty jest punktowanie pracy uczniów; może mieć ono różne formy: od kolorowych gwiazdek lub króliczków wyciskanych z kolorowego papieru (wklejanych do zeszytu), poprzez punkty „tematyczne” (np. znaczki z różdżką podczas omawiania baśni), po esy-floresy przy podpisie Pani pod oceną: im bardziej praca się podobała, tym więcej zakrętasów. W gimnazjum takie formy - jak się okazuje - również mogą być stosowane, ale sporadycznie i żartem, ku uciesze uczniów. Znacznie ważniejsza jest świadomość możliwości poprawy oceny złej lub uznanej przez ucznia za zbyt niską. W liceum z kolei te możliwości ulegają zaostrzeniu - nie można „zaliczać” i poprawiać bez końca, uczeń musi wziąć odpowiedzialność za swoją pracę i jej wyniki. Jeszcze innymi dowodami na pasjonowanie się pracą mogą być: interesujące, prowadzone różnymi metodami, lekcje; atrakcyjne formy rozwijania umiejętności językowych, przekazu wiadomości i ich utrwalania; siła zaangażowania w przedmiot rozważań; omawianie utworów i dzieł sztuki wybranych przez uczniów i spoza wykazu programowego; stosowanie różnych form organizacyjnych klasy podczas lekcji. Każda z przywołanych polonistek stosowała w latach 80. nowatorskie formy pracy (stosuje dzisiaj też inne), wyprzedzając czas, w którym zostały uznane i opisane w literaturze metodycznej: E. Pełzowska uczyła, stosując przekład intersemiotyczny (nie używała wówczas nazwy tej nieznanej jeszcze metody); E. Popiel-Popiołek w sposób nowoczesny omawiała dzieła filmowe, w tym zaliczane do kultury masowej; B. Strzelecka stworzyła w klasie scenę teatralną i odwoływała się do teatralizacji tekstów jako formy omawiania utworów i oddziaływania na ucznia. Zwróćmy uwagę także na chęć organizowania wycieczek, uczestniczenia w tej formie zajęć edukacyjnych 
i przygotowywania uczniów do nich. Wreszcie wspomnieć trzeba o zapoznawaniu się z najnowszą literaturą dydaktyczną i stosowaniem lub choćby tylko próbą zastosowania nowej wiedzy w praktyce.

Ostatnim zespołem cech, które mogły zadecydować o odnoszeniu sukcesów w pracy charakteryzowanych polonistek, są: szacunek dla drugiego człowieka; przejrzystość intencji; akceptacja odmiennego zdania prezentowanego przez ucznia; przyjemność obcowania z istotą niedorosłą i dorastającą; uznanie jej praw; empatia; ogromny ładunek życiowego optymizmu; zaufanie; dystans do swoich osiągnięć, który pozwala cieszyć się z sukcesów, ale nie powoduje wynoszenia się ponad innych. Wszystkie Panie potrafią nawiązać z uczniami niewymuszony kontakt pozalekcyjny, a ich zaangażowanie nie kończy się wraz z dzwonkiem. Charakterystyczna dla ich więzi z uczniami jest pozbawiona cech sformalizowanych potrzeba ciągłej wymiany różnorodnych uwag. Wynika to niewątpliwie również z absolutnej akceptacji młodego człowieka i świadomości, że młodzież może wnieść do życia dorosłych określone wartości, jak choćby optymizm lub oryginalną, odkrywczą ocenę rzeczywistości. Nie znaczy to jednak, że uczeń może zachowywać się nazbyt swobodnie. Uważny obserwator zauważy wyraźnie wytyczoną linię, poza którą żadna ze stron wyjść nie powinna. Wykroczenia ze strony ucznia, w zależności od przewinienia, są rozwiązywane krótko - ostrą uwagą i oceną słowną nagannych zachowań (np. ściągania, odrabiania pracy domowej na lekcji bez zezwolenia nauczyciela, braku szacunku dla kolegów) lub wyrażoną w sposób zdecydowany prośbą; czasem wystarczy tylko znaczące spojrzenie. Wykroczenia nauczyciela, bo i te się zdarzają - wszak jest tylko człowiekiem, zawsze kończą się przeprosinami z jego strony. Wydaje się, że szacunek okazywany uczniowi powoduje równocześnie respekt dla praw nauczyciela i linia wytyczająca granicę jego prywatności rzadko bywa naruszana. Ustalenie pewnych zasad współżycia szkolnego wynika z konsekwencji tych nauczycielek i przejrzystości ich intencji - postrzegają one w uczniu dobro i do jego wydobycia dążą, wierzą też w dobre intencje swoich wychowanków i darzą ich zaufaniem.

Zaprezentowana wyżej charakterystyka lubianych i cenionych przez uczniów oraz ich rodziców nauczycielek zdaje się sugerować, że mamy do czynienia z ucieleśnieniem niedostępnego ideału. Nie jest to prawda - przede wszystkim każda z nich jest inna. Zarysowane wyżej cechy realizują się w przypadku każdej odmiennie, np. zupełnie inaczej pracują na lekcji, w inny sposób rozmawiają z uczniami, różną wagę przywiązują do określonych zachowań uczniów; poza tym mają także wady. Jeśli przyjrzymy się wyróżnionym cechom tych polonistek, to stwierdzimy, że posiadają predyspozycje, które Dawid zawarł w pojęciu „dusza nauczycielstwa”, Mysłakowski, Szuman i Baley - w pojęciu 
"talent pedagogiczny”(Baley nazwał tę cechę „zdatnością pedagogiczną”), Baley i Szuman - w pojęciu „takt pedagogiczny”. Cechy te odpowiadają wielu kompetencjom nauczycielskim, które wyróżnili Stanisław Dylak i Kazimierz Denek. Pierwszy wyodrębnił: kompetencje bazowe, pozwalające nauczycielowi porozumiewać się z dziećmi i współpracownikami; kompetencje konieczne, bez których nauczyciel nie mógłby pełnić swojej funkcji (kompetencje interpretacyjne, autokreacyjne oraz realizacyjne); kompetencje pożądane (zainteresowania i umiejętności związane np. ze sportem lub sztuką) $)^{23}$. Z kolei Denek zwrócił uwagę na: kompetencje informatyczne, uwidaczniające się w umiejętności korzystania z nowoczesnych źródeł informacji; kompetencje współdziałania, charakteryzujące się skutecznością zachowań prospołecznych i sprawnością działań integracyjnych; kompetencje kreatywne, objawiające się w innowacyjności i niestandardowości działań ${ }^{24}$.

Potrzebę istnienia nauczycieli o cechach podobnych do wskazanych wyżej wykazują także inni badacze problemu. Grzegorz Mazurkiewicz proponuje postrzeganie nauczyciela w kategoriach nauczyciela obywatela, ponieważ: jest on odpowiedzialny za rozwój społeczny, dba o prawa i swobody własne oraz innych, świadomie stosuje się do zasad społecznego współżycia, co pozwala społeczeństwu dojrzewać i odnosić sukcesy; zajmuje się realizacją podstawy programowej, ale pomaga uczyć się wszystkim uczniom i uświadamia im, w jaki sposób szkoła wpływa na ich los; przejawia ponadto specyficzne podejście do rzeczywistości jest gotowy na interakcje z każdym współobywatelem i angażuje się lub inicjuje zmiany zarówno na zewnątrz, jak i wewnątrz szkoły ${ }^{25}$. Mazurkiewicz podkreśla przy tym, że „Nauczyciele obywatele dźwigają na swych barkach olbrzymią odpowiedzialność, ale robią to dobrowolnie"26.

\section{CZY POLSKA SZKOŁA POTRZEBUJE RADYKALNYCH ZMIAN?}

G. Mazurkiewicz podkreśla, że:

Na całym świecie podejmuje się intensywne próby poprawienia jakości edukacji. [...] Wśród elementów, które wymagają zmiany, są według [...] inicjatorów [reform] programy i metody nauczania, szkolenie nauczycieli i dyrektorów, systemy

23 S. Dylak, Wizualizacja w ksztatceniu nauczycieli, Poznań 1995 s. 38-39.

24 K. Denek, O nowy kształt edukacji, Toruń 1998, s. 215-217.

25 Por. G. Mazurkiewicz, Nauczyciele - odpowiedzialni obywatele: poradnik pozytywnego myślenia, [w:] Edukacja jako odpowiedź. Odpowiedzialni nauczyciele w zmieniajacym się świecie, red. G. Mazurkiewicz, Kraków 2014, s. 19.

26 Ibidem, s. 22. 
ewaluacji, infrastruktura, organizacja pracy, teoretyczne podejście do procesu nauczania i uczenia się i wiele innych ${ }^{27}$.

Wszystkie te działania łączy, zdaniem badacza, postać nauczyciela. Powinien on być nie tylko inicjatorem zmian, ale również (w Polsce) osobą odpowiedzialną za losy reform, jakkolwiek nie on je inicjuje. Pod adresem nauczyciela i jego pracy kierowane są również różnorakie życzenia i obiekcje. Wątpi się na przykład, czy potrafi tak ukształtować wychowanka, by ten mógł sprostać życiu w społeczeństwie ponowoczesnym oraz potrzebom tego społeczeństwa ${ }^{28}$. Zastrzeżenia wyrażane są w formie twierdzeń, lecz nie zawsze posiadają udokumentowanie w rzeczywistości, jakkolwiek - istotnie - zmiany w podejściu do ucznia i nauczania są konieczne.

Prezentując przykłady nauczycielstwa spełnionego, odrzuciliśmy pogląd głoszący, że nauczyciel nie może uczyć tak, jak dotąd (czyli co najmniej do połowy lat $90 . \mathrm{XX}$ wieku) i jego pracę trzeba radykalnie zmienić. Tymczasem okazuje się, że tak właśnie, jak wcześniej, można uczyć i przy tym osiągać pożądane wyniki, nie czyniąc uczniom krzywdy, a społeczeństwu szkód. Kolejne sądy, na które zwrócimy uwagę, wiążą się z twierdzeniem, że nauczyciel nie jest dziś jedynym medium wiedzy. Czy kiedykolwiek jednak był? Z chwilą, gdy w powszechnym użyciu pojawił się podręcznik, nauczyciel na pewno przestał być jedynym przekaźnikiem wiedzy. Patrząc na pracę nauczyciela od tej strony, należy stwierdzić, że jego rolę ograniczyły: rozwój prasy, kino, radio, telewizja, muzea, biblioteki, udostępniane publiczności zbiory prywatne, organizowane wystawy, ogrody zoologiczne, podróże, wycieczki, prelekcje, spotkania z interesującymi ludźmi, słuchanie opowieści ludzi „ze świata”29. Z taką sytuacją mamy do czynienia od dawna. Jednak rola pedagoga nigdy nie ograniczała się tylko do przekazywania

27 Idem, Wstęp, [w:] Edukacja jako odpowiedź..., s. 9.

28 Większość poruszonych w rozważaniach uwag na temat powinności nauczyciela i potrzeb szkoły ponowoczesnej znajdziemy w artykule Stanisława Gajdy Wychowanie językowe wobec ponowoczesności (op. cit.). Podjęte w tekście rozważania nie są jednak polemiką z uczonym, który dokonał bardzo starannego opracowania sytuacji, wprowadzając do problematyki wychowania językowego. Przytoczone przez niego sądy znajdziemy także w innych publikacjach. Zob. np. Materiaty edukacyjne programu Kreator, Warszawa 1999, s. 7-9; K. Borawska-Kalbarczyk, Umiejętność indywidualnego zarzadzania informacjami jako kompetencja kluczowa w społeczeństwie wiedzy, [w:] Kompetencje kluczowe dzieci i młodzieży. Praktyka edukacyjna, red. J. Uszyńska-Jarmoc, K. Nadachewicz, Warszawa 2015, s. 40.

29 Zwróćmy uwagę na przetrzymywanie w dworkach szlacheckich podróżników, którzy stanowili dla gospodarzy nie tylko rozrywkę w monotonnym życiu, ale też przynosili wieści ze świata, które po wielokroć musieli powtarzać. Przykładem takiej osoby dla nizin społecznych jest Roch z Chłopów Władysława S. Reymonta. 
wiadomości programowych, co podważa głoszone obecnie przekonanie, że nie może być ona zawężona do przekazywania wiedzy. Nie czyniła tego nawet szkoła herbartowska, jakkolwiek praca nauczyciela opierała się w niej na wykładzie. Stworzony przez Johanna F. Herbarta system miał służyć wykształceniu urzędników, a więc posiadał jeszcze cel inny niż tylko przekazanie określonych wiadomości. Z kolei w szkole polskiej okresu zaborów działania wielu nauczycieli były podporządkowane przeciwdziałaniu procesowi wynarodowienia młodego pokolenia.

Nie tylko szkoła i nauczyciel przekazują wiedzę, uczeń uczy się także poza szkołą - to kolejny zideologizowany pogląd, który zresztą nie jest żadnym odkryciem, w dydaktyce bowiem od dawna zastanawiano się, czy jej przedmiotem jest nauczanie-uczenie się zinstytucjonalizowane (Czesław Kupisiewicz) czy też wszelkie uczenie się (Wincenty Okoń). Należy zauważyć, że społeczeństwo stawia szkole określone cele, a wiedza zdobywana poza szkołą posiada inne zadania. Obie powinny być przez uczący się podmiot integrowane i weryfikowane. Procesy te dokonują się w uczniu, szkoła natomiast do nich przygotowuje. Podkreśla się dodatkowo, że nauczyciel nie może być tylko osobą przekazującą wiedzę; jego zadanie polega przede wszystkim na organizowaniu procesu uczenia się ucznia oraz rozwijaniu umiejętności zarządzania informacją, czyli wskazywaniu, jak z niej korzystać. Przede wszystkim nauczyciel nigdy nie był osobą tylko przekazującą wiedzę, nawet gdy metodą, którą się posługiwał - na co już zwrócono uwagę - był wykład. Głosząc takie sądy, zaprzeczamy istnieniu szkoły aktywnej oraz np. pedagogiki Montessori czy Celestyna Freineta. O tym, że nauczyciel od dawna organizował uczenie się ucznia, świadczą choćby zasady nauczania, praca w grupach jako forma organizacyjna klasy oraz stosowane przez niego metody poszukujące. Tym, którzy głoszą ten pogląd, idzie zapewne o jeszcze większy udział i pełną świadomość ucznia w procesie dydaktycznym. To już jednak zupełnie inny problem. Nie można również zgodzić się z opinią, że nauczyciel nie uczy korzystania z informacji. Szkoła to zadanie jak najbardziej spełnia, rozwijając kompetencje językowe, ucząc interpretacji tekstów, zlecając poszukiwanie informacji w dostępnych źródłach, rozwijając zdolności poznawcze i dostarczając podstaw wiedzy, która pozwala ocenić przydatność pozyskanych materiałów, zapoznając z etycznym wykorzystywaniem cudzych osiągnięć, w tym z potrzebą przestrzegania praw autorskich.

Od końca lat 90. XX wieku bezustannie podkreśla się, że celem pracy ucznia nie jest zdobywanie wiedzy, bo ta szybko się dezaktualizuje, a poza tym łatwo ją pozyskać, docierając do odpowiednich kompendiów. Żeby jednak z nich korzystać, należy mieć świadomość, że taka wiedza w ogóle istnieje. Tworzenie w tym celu jej „katalogów” jest równie bezsensowne, jak wprowadzanie niegdyś 
do szkół wiedzy uniwersyteckiej. Szkoła powinna dawać (i dawała) podstawy wiedzy z określonego zakresu i zastanawiać się można jedynie nad tym, jakie treści należy do programów wprowadzać oraz jak odróżnić to, co uczeń powinien znać bezwzględnie od tego, co powinien wiedzieć lub czego powinien mieć tylko świadomość. Wiedza, poza tym że umożliwia uczniowi poznanie świata, powinna ułatwiać jego rozumienie i odnalezienie się w nim, nawet gdy rzeczywistość staje się „płynną nowoczesnością”. Jej zdobywanie służy rozwijaniu sprawności umysłowych (służących m.in. integracji wiedzy szkolnej z pozaszkolną). Nie ukształtujemy w uczniu kreatywności, rzutkości i umiejętności rozwiązywania problemów bez powiązania tego ze zdobywaniem wiadomości. Poznanie bowiem kształtuje zainteresowania. Dewaluacja wiedzy jest więc ze wszech miar niepożądana.

Z omówionymi wyżej twierdzeniami wiążą się następne - ważniejszy niż wiedza jest rozwój umiejętności, które są potrzebne, by szybko odnaleźć się na rynku pracy i radzić sobie w sytuacji wolnorynkowej. Szkoła powinna nauczyć, jak docierać do potrzebnej wiedzy i korzystać ze źródeł informacji. Pierwsze wyraźnie świadczy o urynkowieniu wiedzy, dyktacie pracodawców i ich wglądzie w życie szkoły oraz programy nauczania. „Współczesny świat wymaga od uczniów nowego zestawu umiejętności, dzięki którym będą mogli w pełni korzystać z praw i możliwości rozwijającego się społeczeństwa wiedzy", czytamy w artykule Marcina Polaka pt. Mapa społecznych umiejętności XXI wieku. Opracowanie mapy kompetencji społecznych na miarę wyzwań XXI wieku „uwzględnia również uwagi i oczekiwania amerykańskich pracodawców względem uczniów [podkr. - J.F.]"30. Wydaje się, że pracodawcy mogą jedynie ingerować w pracę szkół zawodowych w ramach kształcenia zawodowego, ale już nie ogólnego, bo przecież jakie mogą mieć wymagania względem uczniów, którzy im jeszcze nie podlegają? Zaczynamy coraz bardziej uwzględniać zdanie pracodawców, nie licząc się z potrzebami ucznia jako człowieka (o czym niżej). Zaczęliśmy nawet lansować twierdzenia, że odpowiednie studia pozwolą zdobyć pracę, a uczeń dopowiedział sobie - pracę dobrze płatną. Tymczasem takich studiów nie ma, ponieważ nawet jeśli aktualnie istnieją, to bardzo szybko proponowane przez nie kształcenie może okazać się nieaktualne. Dobrze przygotowany do trudnej sytuacji na rynku pracy jest człowiek elastyczny, potrafiący się dostosować do zmieniających się warunków, odporny na stres, gotowy do szybkiej zmiany kwalifikacji zawodowych i podjęcia nowych wyzwań, a więc

30 M. Polak, Mapa spotecznych umiejętności XXI wieku, http://edunews.pl/system-edukacji/22-aktualnoci/system-edukacji/522-mapa-spolecznych-umiejetnosci-xxi-wieku [dostęp: 22.09.2017]. 
sprawny językowo i ukształtowany formalnie. Wiedza w żaden sposób tu nie przeszkadza, poszerza natomiast horyzonty myślowe i chroni przed bezmyślnym konsumpcjonizmem i wegetacją. Do twierdzenia, że szkoła powinna nauczyć, jak docierać do potrzebnej wiedzy i korzystać ze źródeł informacji, odniesiono się wcześniej.

Żadnego z zaprezentowanych wyżej twierdzeń o potrzebach zmian w edukacji i pracy nauczyciela nie da się obronić. Głównie narzucają nieprawdziwy ogląd sytuacji (np. ważniejszy niż wiedza jest rozwój umiejętności; szkoła nie uczy korzystania z informacji; pracę nauczyciela trzeba radykalnie zmienić), ale też wprowadzają obce wzory (dyktat pracodawców), a nawet wywołują podświadomy lęk (zmiany są konieczne, inaczej absolwent nie będzie mógł szybko odnaleźć się na rynku pracy i radzić sobie w sytuacji wolnorynkowej). Zmiany powinny wynikać przede wszystkim z rozpoznania potrzeb uczniów i społeczeństwa oraz ogólnej sytuacji społeczno-kulturowej. Ich wprowadzenie należałoby poprzedzić szeroko zakrojonymi badaniami: nie mogą być skutkiem pośpiechu, lęków, a tym bardziej zaszczepianiem obcych wzorów. Tymczasem ani nie prowadzi się takich badań, ani nie posiadamy dobrego rozeznania w potrzebach społeczeństwa ponowoczesnego.

\section{ZAKOŃCZENIE}

Gwałtowne wtargnięcie w ponowoczesność z wszystkimi wynikającymi z tego konsekwencjami wywołało chaos myślowy i dezorientację Polaków. Dodatkowo przykra okazała się świadomość, że „miało być lepiej, a było coraz gorzej" i wcale nie dotyczyło to gospodarki: obserwowaliśmy dewaluację intelektu, odrzucenie wiedzy i prawdy jako wartości oraz zastąpienie tych wartości przez relatywizm kulturowy, posiadający - jak to określił Frank Furedi - wszelkie znamiona prądu intelektualnego. Przyczyniło się to, jego zdaniem, do uznania wiedzy potocznej za równoważną uniwersyteckiej, do niszczenia akademickiej wolności, narodzin kultu banalności, ogólnego obniżenia poziomu nauki, kultury i sztuki ${ }^{31}$. Tendencje te wpłynęły destrukcyjnie na pracę szkoły i postrzeganie funkcji nauczyciela w życiu młodego pokolenia. Od czasu transformacji społeczno-ustrojowej przełomu XX i XXI wieku oraz ukazania się prac Zygmunta Baumana: Ptynnej nowoczesności (Cambridge 2000; Kraków 2006) i Życia na przemiat (Cambridge 2004; Kraków 2004), podejmujących problemy społeczeństw ponowoczesnych, minęło jednak wystarczająco dużo czasu, by pokusić się o stwierdzenie, że w naszej historii mieliśmy do czynienia

31 F. Furedi, Gdzie się podziali wszyscy intelektualiści?, Warszawa 2008. 
ze znacznie trudniejszymi problemami niż te, które przyniosła rzeczywistość „płynnej ponowoczesności”. Czas więc na spokojniejsze rozważenie problemów współczesnej edukacji i jej zadań, minione dwudziestolecie przyniosło bowiem wiele niepokojących zmian:

Zmiany te obejmują: (1) powstawanie prywatnych, komercyjnych instytucji w systemie edukacji publicznej; (2) uczynienie konkurencyjności jedynym [podkr. autora] uzasadnieniem dla edukacji oraz (3) dominację pomiarów, testów i rankingów w ocenie jakości szkoły. Zmiany wynikają z globalnej dyskusji o edukacji, zbyt często sprowadzającej uczenie się (i nauczanie) do towaru wymiennego, który należy dokładnie zmierzyć i porównać, nie myśląc o humanistycznym zaangażowaniu opartym na wzroście i rozwoju społecznym oraz dziecku takim, jakie ono jest i jakim się staje. Jak na ironię, ukierunkowanie edukacji na ekonomię zamiast na człowieka ma miejsce w czasie nasilających się problemów globalnych, którym ani kapitał, ani obecne rządy nie są w stanie zaradzić za pomocą dostępnych struktur ${ }^{32}$.

Wiek XXI zdecydowanie nie jest początkiem końca szkoły i zawodu nauczyciela, mimo istnienia alternatywnych form kształcenia:

Współczesność nieustannego kryzysu wymusza wzór człowieka, który może sprostać okolicznościom i zadaniom. Człowieka pełnomocnego - o ukształtowanych kompetencjach intelektualnych do formułowania i rozwiązywania nowych, trudnych zadań, człowieka mądrego, odpowiedzialnego, współczulnego i zdolnego do solidarnego współdziałania, zdolnego do radzenia sobie na coraz trudniejszym rynku pracy, umiejącego krytycznie wybierać z wielorakich i migotliwych ofert kulturalnych wedle uniwersalnych wartości i zasad ${ }^{33}$.

Społeczeństwo wciąż potrzebuje mądrych i odpowiedzialnych obywateli, nic więc w zakresie wymagań stawianych nauczycielowi nie uległo zmianie. Ponadto potrzeby współczesnego dziecka są takie same, jak dzieci żyjących kilkadziesiąt lat temu - potrzebuje ono mądrego, życzliwego, świadomego swojej roli i dobrze wykształconego przewodnika. Zdaniem Józefa Kuźmy:

32 W. Gaudelli, Edukacja humanistyczna w dobie globalizacji, [w:] Edukacja jako odpowiedź...

33 Z. Kwieciński, Dtugotrwate ślady dzieciństwa, [w:] Dziecko. Sukcesy i porażki, red. R. Piwowarski, Warszawa 2007, s. 109. 
[...] nauczyciel szkoły przyszłości, który ma sprostać coraz bardziej złożonym zadaniom, powinien być przede wszystkim mądrym, sprawiedliwym, empatycznym oraz dobrym, przyzwoitym, spolegliwym człowiekiem. Dlatego powinien być człowiekiem wielowymiarowym, a zarazem wysokiej klasy specjalistą w wybranej dyscyplinie ${ }^{34}$.

Przedstawione wcześniej postawy zawodowe polonistek spełniają warunki zaproponowane przez Kuźmę dla nauczycieli szkoły przyszłości. Prezentowane przez nie cechy zawodowe charakteryzowały również - co warto podkreślić nauczycieli z początku wieku XX, a nawet wieku XIX. Są to więc cechy ponadczasowe i z pewnością nie trafią do lamusa historii myśli pedagogicznej. Należy zwrócić uwagę na jeszcze jeden aspekt pracy prezentowanych $\mathrm{w}$ artykule polonistek. Są one nauczycielkami z powołania, dlatego mogą czuć się zmęczone, ale nie są wypalone zawodowo. Lubią uczyć i czynią to z pasją. Ponowoczesność - jak zauważono wcześniej - przestała już niepokoić, choć ciągle zaskakuje zmianami. Można więc spokojniej podejść do kształcenia szkolnego, wykorzystać w nim wypracowane osiągnięcia polskiej dydaktyki, zastanowić się nad wzorami obcymi, przywrócić istnienie podmiotowości nauczyciela, a podmiotowość ucznia spożytkować z korzyścią dla niego.

\section{BIBLIOGRAFIA}

Abd Elsamie M., Profesja nauczyciela w Arabskiej Republice Egiptu, „Edukacja i Dialog” 2015, nr 1-2.

Baley S., Psychologia wychowawcza w zarysie, Warszawa 1958.

Bauman Z., Ptynna nowoczesność, Kraków 2006.

Bauman Z., Życie na przemiat, Kraków 2004.

Borawska-Kalbarczyk K., Umiejętność indywidualnego zarzadzania informacjami jako kompetencja kluczowa w spoteczeństwie wiedzy, [w:] Kompetencje kluczowe dzieci i młodzieży. Praktyka edukacyjna, red. J. Uszyńska-Jarmoc, K. Nadachewicz, Warszawa 2015.

Chhabra E., Teacher - popyt na nauczyciela w Wielkiej Brytanii, „Edukacja i Dialog” 2015, nr 1-2.

Dawid J.W., O duszy nauczycielstwa, Warszawa 1912.

34 J. Kuźma, Przyszła szkoła będzie w większym niż obecnie stopniu skoncentrowana na uczniach, Rozmowa z prof. zw. dr. hab. Józefem Kuźmą przeprowadzona przez Darię Grodzką, „Hejnał Oświatowy” 2013, nr 4, http://img.iap.pl/s/245/8148/Edytor/File/2013_ROK/Wywiad_ Profesor_Jozef_Kuzma.pdf [dostęp: 22.09.2017]. 
Denek K., O nowy kształt edukacji, Toruń 1998.

Dylak S., Wizualizacja w kształceniu nauczycieli, Poznań 1995.

„Edukacja i Dialog” 2015, nr 1-2.

Furedi F., Gdzie się podziali wszyscy intelektualiści?, Warszawa 2008.

Gajda S., Wychowanie językowe wobec ponowoczesności, [w:] Wychowanie językowe, red. J. Nocoń, Opole 2015.

Gaudelli W., Edukacja humanistyczna w dobie globalizacji, [w:] Edukacja jako odpowiedź. Odpowiedzialni nauczyciele w zmieniającym się świecie, red. G. Mazurkiewicz, Kraków 2014.

Goban-Klas T., Nowa edukacja medialna w społeczeństwie ryzyka i katastrof, „Edukacja i Dialog" 2010, nr 9.

Khachatryan R., Ormiański nauczyciel - jeden z głównych filarów narodu, „Edukacja i Dialog” 2015, nr 1-2.

Kołodziejczyk W., Polak M., Jak będzie zmieniać się edukacja. Wyzwania dla polskiej szkoty i ucznia, Warszawa 2011.

Kompetencje wspótczesnego polonisty, red. B. Chrząstowska, Warszawa 1997.

Kowalikowa J., Składniki polonistycznej kompetencji nauczycielskiej, „Zeszyty Naukowe UJ. Prace Historycznoliterackie" 1982, z. 44.

Kuźma J., Nauczyciele przyszłej szkoły, Kraków 2001.

Kuźma J., Przyszła szkoła będzie w większym niż obecnie stopniu skoncentrowana na uczniach, Rozmowa z prof. zw. dr. hab. Józefem Kuźmą przeprowadzona przez Darię Grodzką, „Hejnał Oświatowy” 2013, nr 4, http://img.iap.pl/s/245/8148/Edytor/ File/2013_ROK/Wywiad_Profesor_Jozef_Kuzma.pdf [dostęp: 22.09.2017].

Kwaśnica R., Wprowadzenie do myślenia o nauczycielu, [w:] Pedagogika. Podręcznik akademicki, red. Z. Kwieciński, B. Śliwerski, t. 2, Warszawa 2003.

Kwieciński Z., Długotrwałe ślady dzieciństwa, [w:] Dziecko. Sukcesy i porażki, red. R. Piwowarski, Warszawa 2007.

Materiaty edukacyjne programu Kreator, Warszawa 1999.

Mazur P., Zawód nauczyciela w ciagu dziejów. Skrypt dla studentów z historii wychowania, Chełm 2015.

Mazurkiewicz G., Nauczyciele - odpowiedzialni obywatele: poradnik pozytywnego myślenia, [w:] Edukacja jako odpowiedź. Odpowiedzialni nauczyciele w zmieniajacym się świecie, red. G. Mazurkiewicz, Kraków 2014.

Mazurkiewicz G., Wstęp, [w:] Edukacja jako odpowiedź. Odpowiedzialni nauczyciele w zmieniającym się świecie, red. G. Mazurkiewicz, Kraków 2014.

Mysłakowski Z., Pisma wybrane, Warszawa 1971.

Plewka C., Uwarunkowania zawodowego rozwoju nauczycieli, Warszawa 2009.

Polak M., Mapa społecznych umiejętności XXI wieku, http://edunews.pl/system-edukacji/22-aktualnoci/system-edukacji/522-mapa-spolecznych-umiejetnosci-xxi-wieku [dostęp: 22.09.2017].

Profesjonalny coach, czyli kto?, www.competitiveskills.pl/aktualnosci/profesjonalnycoach-czyli-kto-226.html [dostęp: 22.09.2017].

Schulz R., Nauczyciel jako innowator, Warszawa 1989.

Szuman S., Takt pedagogiczny, Katowice 1974. 
Tapscott D., Cyfrowa dorostość. Jak pokolenie sieci zmienia świat, Warszawa 2010. Tkaczyk A., Nauczyciel a edukacja w Turcji, „Edukacja i Dialog” 2015, nr 1-2.

Tomasik-Abdelsamie K., Nauczyciel w Niemczech, „Edukacja i Dialog” 2015, nr 1-2. Troc-Rezaiguia M., Kim jest dzisiejszy francuski nauczyciel, „Edukacja i Dialog” 2015, nr $1-2$.

Tutoring - poznaj innowacyjna metodę, http://tutoring.edu.pl/tutoring_definicja_innowacyjna_metoda,page,46 [dostęp: 22.09.2017].

Urbaniak K., Kim jest coach i co może dla Ciebie zrobić - wywiad z Adamem Gieniuszem, http://kreatorniazmian.pl/kim-jest-coach-co-to-jest-coaching/\#sthash.uQrsU6oi. dpuf [dostęp: 22.09.2017].

W kręgu danych $i$ współczesnych teorii wychowania. Uczeń - szkoła - nauczyciel, red. K. Dormus, R. Ślęczka, Kraków 2012.

Zadroga A., Coach, czyli kto?, http://wyborcza.pl/1,76842,8563661,Coach_czyli_kto_. html [dostęp: 22.09.2017].

Summary: The author examines the actions of four Polish language teachers and criticises current claims concerning the need for changes in teachers' way of working and in teaching itself. On this basis, she argues that the $21^{\text {st }}$ century is not the beginning of the end of school and teaching, despite the existence of other, alternative forms of educating students. In her conclusion, the author claims that teenagers still need a teacher who will be a wise, kind, aware of his/her role and well-educated leader. Post-modernism no longer evokes anxiety, although it continues to surprise with various changes. Thus, the issue of education at schools may be approached in a calmer manner, with the employment of already created Polish didactics; what is more, foreign patterns should be taken into consideration.

Keywords: teacher; teaching; needs of a post-modern school 